\title{
19th and 20th Century Plant Hunters
}

\author{
Allan Stoner ${ }^{1}$ \\ USDA ARS National Germplasm Resources Laboratory, Beltsville, MD 20705 \\ Kim Hummer ${ }^{2}$ \\ USDA ARS National Clonal Germplasm Repository, 33447 Peoria Road, Corvallis, OR 97333-2521
}

\begin{abstract}
Additional index words. Plant genetic resources, germplasm, plant exploration
Abstract. The latter part of the 19th and the first several decades of the 20th century can be described as a "golden age" for plant exploration and collecting. During the initial years of this period, agricultural scientists from the United States and elsewhere devoted considerable resources to collecting potential new crops for farmers as well as superior plants or cultivars of the species that farmers were already growing. Over time, there was a shift toward collecting unadapted germplasm, or raw material that possessed traits that plant breeders and other scientists could use for cultivar improvement and other types of research. Although many institutions and individuals were involved in plant collecting during this period, the creation of the U.S. Department of Agriculture (USDA) Office of Seed and Plant Introduction in 1898, resulted in the largest single program devoted to plant exploration. This office employed many individuals, including David Fairchild, P.H. Dorsett, Frank Meyer, Walter Swingle, and Wilson Popenoe. These and many other individuals collected-and introduced into the United States-seeds and plants of thousands of fruits, vegetables, nuts, ornamentals, cereals, forages, oilseeds, and other types of crops. Although the mission of most of the plant explorations during this period was to collect any plants that appeared interesting or potentially useful, others focused on collecting targeted species. Much of the material collected during this era is still maintained by the U.S. National Plant Germplasm System (NPGS), and much more of it shows up in the pedigrees of cultivars grown by farmers and gardeners today. In addition to collecting plants for immediate and future use, scientists of this era, such as Nicolai I. Vavilov and Jack Harlan, contributed greatly to the understanding of the evolution of plants and plant genetic diversity, and the interdependence of plants and civilization.
\end{abstract}

Plant introductions (PIs) into the United States have come from thousands of sources: immigrants, tourists, government officials. The first official PI activities by the United States government were conducted in the late 1700 s and early 1800 s when naval officers and diplomats sent germplasm back to the United States. The latter part of the 19th and the first several decades of the 20th century can be described as a "golden age" for plant exploration and collecting. During the initial years of this period, agricultural scientists from the United States and elsewhere devoted considerable resources to collecting potential new crops for farmers, as well as superior plants or cultivars of species that farmers were already growing. This paper will discuss the earliest USDA explorers through those of the middle of the 20th century.

\section{MIDDLE TO LATE 1800S: FIRST} UNITED STATES PLANT EXPLORERS

The first official federal United States foreign plant exploration was conducted in 1858. On this trip, Robert Fortune collected tea, Camellia sinensis L., from China. This trip occurred before the establishment of the U.S. Department of Agriculture (USDA). Mr. Fortune was sponsored by the U.S. Commissioner of Patents.

\footnotetext{
The cost of publishing this paper was defrayed in part by the payment of page charges. Under postal regulations, this paper therefore must be hereby marked advertisement solely to indicate this fact. ${ }^{1}$ Supervisory Horticulturist, Retired.

${ }^{2}$ Research Leader/Curator;

E-mail khummer@ars-grin.gov
}

Private collections and botanical gardens were interested in exotic plants. Professor Charles S. Sargent was the first Director of the Arnold Arboretum, Jamaica Plain, Mass. In 1892, he inaugurated the Arboretum's interest in eastern Asia by visiting Japan. The Arnold Arboretum subsequently provided the foundation plant material for the introduction of many Japanese plants into American gardens. Ernest H. Wilson, also under the employ of the Arnold Arboretum, undertook four major expeditions to China between 1899 and 1911. He spent most of the second decade of the 20th century exploring for plants in Japan, Korea, and Taiwan.

Although many institutions and individuals were involved in plant collecting during this period, the creation of the USDA Section of Foreign Seed and Plant Introduction (SPI) resulted in the largest single program devoted to plant collection and exploration in the United States (White and Briggs, 1989). James "Tama Jim" Wilson, previously the Director of the Iowa Experiment Station, was appointed to be Secretary of the USDA. He appointed David Fairchild, who was at that time 22 years old, to be Chief of the Section and Professor Niles Ebbesen Hansen to be the first official plant explorer for the USDA. Secretary Wilson stated, "I have twelve thousand men under me, but none who knows how to work like Hansen. There is only one Hansen." Indeed Professor Hansen was a very productive collector. Fairchild (1944) states that, "Almost the moment I was settled in our first location, tons of seeds and plants began to pour in upon me from Russia. Hansen felt that he had been sent out to collect, and he collected everything and collected it in quantity. It was all most embarrassing, as no provision whatever had been made to take care of his shipments."
Professor Hansen was supported on three USDA plant collecting trips to Russia for 10 months in 1897, to Turkistan for 6 months in 1906, and in Europe and Siberia for 9 months in 1908. On these trips, he collected alfalfa and other forage germplasm, plus apples, pears, crabapples, and small fruits. The plant material that he collected was rich in cold-hardiness and drought tolerance.

\section{EARLY 1900S PLANT EXPLORERS}

Mark A. Carleton, a classmate of David Fairchild's, was a USDA wheat breeder who was working to discover rust resistance in cereals. He had been studying Russian, and in the course of his reading he concluded that the Black Lands of Russia could contain resistant strains of wheat. Fairchild asked him to travel to Russia in 1898 to collect wheat, barley, and other cereals. Carleton brought back "durum wheat," a special class of early wheat, which prefers dry conditions and is very productive. The spectacular success of durum wheat focused public attention on the value of PI. It demonstrated that farmers could achieve high profits as a result of the introduction of a new variety. Two years after the introduction of durum wheat, 60,000 bushels were produced; only 5 years later, 20,000,000 bushels were grown (Fairchild, 1944).

Fairchild himself traveled to distant reaches of every continent but Antarctica between 1896 and 1933. He searched for fruits, vegetables, cereals, and other economic plants, including mangos, dates, nectarines, and flowering cherries. During his career he and those who worked under him introduced more than 80,000 accessions into the United States.

Many USDA employees from the Section of Plant Pathology were also involved with 
PI. Some of these included Walter T. Swingle, Frank N. Meyer, Fredrick Wilson Popenoe, and P. Howard Dorsett. As Harry V. Harlan (Harlan and Harlan, 2005) describes, "The pioneers of plant industry were as amazing a lot as those who had pushed back our frontiers. They were striking individualists with no two having the same background or any distant resemblances...each brilliant in one way or another-but where in God's world did they find them?"

Walter T. Swingle delivered his first scientific paper at the age of 16 . He received a B.S. from Kansas State University at 19 years of age. He joined USDA in 1891 and became an agricultural explorer in 1898. He made many trips to southern Europe, North Africa, the Near East, China, Japan, and the Philippines. He introduced many citrus varieties and unusual species relatives.

Frank N. Meyer traveled over a thousand miles along the routes of Marco Polo across Asia (Cunningham, 1984) He spent 13 years in eastern and northern China collecting samples of any plant that looked interesting. However, he primarily focused on what he thought would be economically useful. $\mathrm{He}$ sent over 2500 PIs to the United States as live cuttings and thousands of sacks of seed. His introductions included plants from alfalfa to zoysia grass. During his long periods of travel, Meyer had to deal with threatening robber brigands, wolf packs, revolutionary soldiers on the prowl, interpreters who refused to go on, carts that shattered on lonely mountainsides, inadequate food, poor shelter, and vermin that infested Asian villages. Meyer returned "tired, but satisfied," from a successful expedition in the high mountains of Shanxi Province in northern China on 26 Feb. 1908. Frank Meyer unexpectedly died while traveling on the Yangtze River in China during his final expedition in 1918. The inscription on the tombstone on Meyer's grave at Bubbling Wells Cemetery, Shanghai, China, reads, "In the glorious luxuriance of the hundred plants he takes delight." The Meyer Medal, an annual award presented by the Crop Science Society of America, originated in 1918. It is presented in honor of Frank N. Meyer, as a result of funds bequeathed to the Plant Introduction Section in his will. This medal is presented to recognize an individual with stellar meritorious work in the field of Plant Genetic Resources.

Frederick Wilson Popenoe was a USDA agricultural explorer from 1912 to 1925 . He had an eye for economic crops with potential value to the United States. He specialized in South American crops and was largely responsible for popularizing avocadoes in America.

Palemon Howard Dorsett, another USDA agricultural explorer, collected nearly 3000 soybean accessions in China, Japan, Manchuria, and Korea between 1929 and 1930. Explorations by Dorsett and others during the years 1906-1932 yielded 5534 soybean accessions. None of the original 114 PIs from 1906 to 1917 were saved; all were distributed to users. At that time, no germplasm repositories existed for long term maintenance of originally collected germplasm. Now, 24 PIderived cultivars are part of the United States collection (GRIN, 2005).

Harry V. Harlan joined the USDA, Bureau of Plant Industry, in 1910 and was "young, eager, and thirsty for new discoveries." Harlan collected barley in Russia, Ethiopia, North Africa, and other areas. "The desire to explore and to collect is as inherent in us and as much a part of us as toenails and far less transitory than hair. Who has not felt the urge to go places and do things? Any boy old enough to walk spends most of his time exploring, and his mother is in a perpetual state of dismay over the treasure he collects. My urge to explore the world and the desire to collect barleys need no word of explanation. I wanted to go so badly that I would not have blamed those in power if they had harbored a suspicion that my eagerness was as much for personal pleasure as for the good of the cause..." Harlan stated that "I never for a moment doubted the material thus obtained would justify the expense of the trip many times over." He thought that, "The whole record of American agriculture was made up of a succession of crops that came from a handful of seed-crops with annual revenues to the farmers valued in the hundreds of millions." Harlan was also aware that, "Unfortunately too few Americans realize what introductions of foreign crops has meant to the American way of life."

Although we have been discussing American plant explorers, one Russian, Nicolai Ivanovich Vavilov, was extremely instrumental at defining the need for plant exploration as a foundation for agricultural development. Between 1916 and 1940, Vavilov made expeditions to five continents in search of new agricultural plants and confirmation of his theories on plant genetic diversity. His principal work was a scientific survey of his travels and explorations (Vavilov, 1997). He participated in more than 100 plant-collecting expeditions. He obtained plants from Afghanistan, Uzbekistan, the Mediterranean Region, Germany, China, Japan, Korea, United States, Canada, Iran, Cuba, Central and South America, the Caucasus, and Middle Asia. Unfortunately, due to political differences, Vavilov was arrested in 1940. By that time, the collection of cultivated plants in the Soviet Institute of Plant Industry amounted to 200,000 specimens due to his efforts.

\section{MID-1900S USDA PLANT EXPLORERS}

Jack R. Harlan, son of Harry Harlan, devoted his career to studying the evolution of plants, plant exploration, and the interdependence of plants and civilization. His collected work rivaled that of Vavilov, and his insights on centers of crop diversity clarified, corrected, and extended Vavilov's concepts. Jack Harlan stated, "For the sake of future generations, we MUST collect and study wild and weedy relatives of our cultivated plants as well as the domesticated races. These sources of germplasm have been dangerously neglected in the past, but the future may not be so tolerant. In the plant breeding programs of tomorrow, we cannot afford to ignore any source of usable genes" (Harlan and Harlan, 2005).

While the history of recent plant exploration is rightly dominated by a handful of legendary collectors, many others have made important contributions. In 1948, Jack Harlan and Turkish colleague Osman Tosun collected a wheat sample from a field in Turkey that looked terrible. It lodged, had no winterhardiness, and was susceptible to leaf rust. Harlan wrote of the wheat, PI 178383, "it was a hopelessly useless wheat but was dutifully conserved" (Harlan and Harlan, 2005). However, 15 years later, when United States wheat breeders were looking for resistance to a stripe rust outbreak, PI 178383 was found to have resistance to 4 races of stripe rust, 35 races of common bunt, and 10 races of dwarf bunt, as well as tolerance to flag smut and snow mold. Today PI 178383 appears in the pedigree of virtually all of the wheat grown in the Pacific Northwest.

Joseph J. Rock, Professor of Chinese and Botany at University of Hawaii from 1907 to 1920, collected economic plants for the USDA from 1920 to 1949 . He was sent by the USDA to India to find Taraktogenos kurzii, a tree called the "kalaw" by native tribesmen. A dark-colored oil called "chaulmoogra" reputed to be a cure for leprosy was extracted from the tree.

During his expedition, he faced a maneating tiger, a "rouge" elephant, and a typhoon, but he came back with the seed.

In the 1930s, Howard Scott Gentry collected and mapped the plants of northwest Mexico. He searched for rubber substitutes in the early 1940s. As a USDA botanist and agricultural explorer from 1950 to 1971 , he collected a wide diversity of plant germplasm, including beans and agave from Mexico, cereals and peas from Ethiopia, new crops from South America and the United States, and forage species from the Balkans.

Many explorers continued to collect germplasm during the 1930s. Due to world conflicts in the 1940s, the number of plant exploration trips dropped significantly. The 1950s brought a new surge of explorations.

Harold Olmo was a Professor of the University of California, Davis. He was hired after prohibition to conduct viticultural research. While conducting research to develop improved grape varieties, he traveled the world to study and collect grape germplasm. He introduced hundreds of grape cultivars from Greece, Portugal, Spain, and the Middle East to the United States.

Plants with ornamental value, as well as food and fiber crops were introduced by plant explorers into the United States. For example, in 1957, John Creech introduced Japanese mums for the USDA and Longwood Gardens. 
In 1970, Harold Winters introduced the New Guinea Impatiens into the United States.

Dr. Charles M. Rick, Professor in the Department of Vegetable Crops at the University of California, Davis, did significant plant exploration. During a career that spanned more than 60 years, Dr. Rick traveled extensively throughout the Andean region of western South America collecting the wild relatives of the tomato.

The intercontinental transfer and exchange of crops between Old and New Worlds has radically changed the nature of global agriculture over many centuries. Through the 19th century and the early decades of the 20th century, exploration was focused on broad goals. Although some explorations were focused on specific crops or crop groups, typically any plant of potential value was a target. Increasingly, explorations focused on specific crops and toward collecting germplasm with specific plant characteristics for use in cultivar improvement and other types of research.

\section{Literature Cited}

Fairchild, D. 1944. The world was my garden. Charles Scribner's Sons, New York. 494 pp.

Cunningham, I. 1984. Frank N. Meyer, plant hunter in Asia. Iowa State University Press, Ames. $317 \mathrm{pp}$.

GRIN. 2005. USDA, ARS, National Genetic Resources Program. Germplasm Resources
Information Network- $(G R I N)$. [Online Database] National Germplasm Resources Laboratory, Beltsville, Md. 5 Dec. 2005. http:// www.ars-grin.gov/npgs/index.html.

Harlan, J.R. and H.V. Harlan. 2005. Jack R. \& Harry V. Harlan papers, 1905-85. 5 Dec. 2005. http://web.library.uiuc.edu/ahx uaccard/UAControlCard.asp? RG $=8 \& \mathrm{SG}=$ $6 \& \mathrm{RS}=25$

Vavilov, N.I. 1997. Five continents. International Plant Genetic Resources Institute, Rome. 198 pp. [English translation, Doris Love].

White, G. and J.A. Briggs. 1989. Plant germplasm acquisition and exchange, p. 405-418. In: Biotic diversity and germplasm preservation, global imperatives. Kluwer Academic Pub., Boston. 